\title{
Plant growth regulation: a method for fine-tuning mepiquat chloride rates in cotton ${ }^{1}$
}

\author{
Fábio Rafael Echer ${ }^{2}$, Ciro Antonio Rosolem ${ }^{3}$
}

\section{ABSTRACT}

Plant growth regulator management has been a challenge for cotton growers, due to the increased weather instability and the adoption of early cultivars, in off-season crops. This study aimed at proposing a new method, called Crop Growth Rate, to define mepiquat chloride rates in cotton crops, as well as to compare it with traditional management practices. Except for micronaire, there was no difference in cotton growth parameters, neither in yield nor fiber quality, between the new method and the traditional one. The mepiquat chloride rates were, on average, $24 \%$ higher and $43 \%$ lower in late and early maturity cultivars, respectively, for the new method. The number of bolls in plants treated with mepiquat chloride was lower than in non-treated plants, for the IMA5672B2RF and IMA5675B2RF cultivars, but a higher average weight of bolls was observed for these genotypes. The new method is efficient in defining the plant growth regulator rate to avoid an excessive growth and results in less mepiquat chloride applied to early cycle cultivars, preserving lint yield and fiber quality.

KEY-WORDS: Gossypium hirsutum L.; plant growth regulator; fiber quality.

\section{INTRODUCTION}

Cotton (Gossypium hirsutum L.) is grown in a wide range of environments. Under a tropical environment, plants are exposed to excessive rain early in the season, combined with sunny and warm days, which usually result in rank growth and selfshading. These responses include stem elongation (Wang et al. 2014) and changes in leaf shape and size (Aphalo \& Ballare 1995). To avoid this, plant growth regulators (PGR) are used to modulate plant canopy and improve radiation use efficiency later in the season. Kerby et al. (1986) observed a higher boll

\section{RESUMO}

Controle de crescimento da planta: um método para ajustar doses de cloreto de mepiquate em algodoeiro

O manejo de reguladores de crescimento tem sido um desafio para cotonicultores, devido ao aumento da instabilidade climática e adoção de cultivares precoces, em segunda safra. Objetivou-se propor um novo método, denominado Taxa de Crescimento da Cultura, para definir doses de cloreto de mepiquate em lavouras de algodão, bem como compará-lo com práticas de manejo tradicionais. Exceto para micronaire, não houve diferença nos parâmetros de crescimento do algodoeiro e nem na produtividade e qualidade de fibra, entre o novo método e o tradicional. As doses de cloreto de mepiquate foram, em média, $24 \%$ maiores e $43 \%$ menores em cultivares tardias e precoces, respectivamente, no novo método. O número de capulhos em plantas tratadas com cloreto de mepiquate foi menor do que nas plantas não tratadas, nas cultivares IMA5672B2RF e IMA5675B2RF, mas o peso médio do capulho foi maior nestes genótipos. O novo método é eficiente na definição da dose de regulador de crescimento para evitar crescimento excessivo em cultivares de algodão e resulta em menos cloreto de mepiquate aplicado a cultivares precoces, preservando-se a produtividade e a qualidade da fibra.

PALAVRAS-CHAVE: Gossypium hirsutum L.; regulador de crescimento vegetal; qualidade da fibra.

set at lower nodes and fewer at the top, if compared with non-treated plants, and Zhao et al. (2017) reported an increase in lint yield, as a result of PGR application in early cotton growth stages. However, this response was dependent of environmental conditions and cultivar.

Mepiquat chloride, a gibberellic acid synthesis inhibitor, is one of the most widely used growth regulators in cotton. The impact of mepiquat chloride on stem elongation and plant height are temperature dependent (Reddy et al. 1992) and, at high temperatures, higher PGR rates are needed to control plant growth (Rosolem et al. 2013). The PGR

1. Manuscript received in Feb./2017 and accepted for publication in Aug./2017 (http://dx.doi.org/10.1590/1983-40632016v4745540).

2. Universidade do Oeste Paulista, Presidente Prudente, SP, Brasil. E-mail: fabioecher@unoeste.br.

3. Universidade Estadual Paulista, Faculdade de Ciências Agronômicas, Departamento de Agricultura, Botucatu, SP, Brasil. E-mail: rosolem@fca.unesp.br. 
management in cotton crops has been a challenge for growers, as weather instability has increased in recent years. Furthermore, the adoption of early cycle cultivars as relay crops, with lower daily growth rate, demand lower PGR rates, and the use of Bt cotton cultivars with high and early boll set renders PGR management more complex.

According to Ferreira (2014), the total PGR amounts to be applied at high, medium and low plant heights are 85-100 g a.i. ha ${ }^{-1}, 60-85 \mathrm{~g}$ a.i. $\mathrm{ha}^{-1}$ and $\leq 50 \mathrm{~g}$ a.i. ha ${ }^{-1}$, split in four applications $(10 \%$, $20 \%, 30 \%$ and $40 \%$ of the total rate, respectively). However, cotton growth and its response to PGR application is highly dependent on temperature and water availability, which are not considered in this recommendation.

When cotton is grown in tropical regions with a long growing season (approximately 160-210 days), there is a high probability of rank growth, and an easily applicable method for fine-tuning mepiquat chloride rates in cotton would help in the decision-making to manage the mepiquat chloride use. Despite the existence of crop growth simulations with good anticipation of mepiquat chloride rates and application time ( $\mathrm{Gu}$ et al. 2014), an extensive area cultivated with cotton around the world is located in countries where these resources are not readily available to farmers, or where farmers are not prepared to use these resources. Hence, it is important that the mepiquat chloride recommendation method be simple and easy to apply.

Our hypothesis is that cotton growth is highly dependent on its genetics, as well as the interaction between cultivar and environment, and this interaction may increase/decrease the cotton mepiquat chloride requirements as a function of the amount of dry matter accumulation. Thus, the aims of this study were: i) to propose a new method for defining mepiquat chloride rates in cotton fields; ii) compare this method with traditional management practices; iii) evaluate the effect of mepiquat chloride application using the proposed method in cotton cultivars with different growth cycles.

\section{MATERIAL AND METHODS}

A preliminary experiment (Experiment 1) was conducted to obtain a dry matter estimate to facilitate field measurements. Cotton (Gossypium hirsutum cv. Delta Opal) plants were grown in 12-L pots, in a greenhouse at the Universidade Estadual Paulista, in Botucatu, São Paulo state, Brazil. Eight pots containing two cotton plants each were grown for 57 days, with two replications, and harvest at 39, 45, 51 and 57 days after emergence (DAE), to determine the shoot dry weight, plant height and leaf area, and a curve was fitted (Figure 1).

Since it is impossible to determine the plant dry matter in the field without harvesting the plant, the shoot dry weight was estimated by a regression model based on plant height. This equation was used to estimate the growth regulator concentration in the plants. These plants did not receive PGR application. The regression model of plant shoot dry weight with plant height is shown in Figure 1. A close and significant $(\mathrm{p}<0.05)$ correlation was found, with a coefficient of determination $\left(\mathrm{R}^{2}\right)$ of 0.98 , suggesting that the plant height measurement at field conditions may be a useful tool to estimate the plant dry weight.

Another experiment (Experiment 2) was conducted to determine the plant growth rate and PGR retention on plant leaves. Mepiquat chloride rates $\left(0 \mathrm{~g} \mathrm{ha}^{-1}, 7.5 \mathrm{~g} \mathrm{ha}^{-1}, 15 \mathrm{~g} \mathrm{ha}^{-1}\right.$ and $\left.22.5 \mathrm{~g} \mathrm{ha}^{-1}\right)$ were applied at the pinhead square stage, at $39 \mathrm{DAE}$, and a solution of Blue Brilliant (FDandC n.1), a color additive, was added to the spray solution at $3,000 \mathrm{mg} \mathrm{L}^{-1}$. Leaves from treated plants were collected, washed and the water used was analyzed by spectrophotometry. The amount of product retained in the leaves was calculated.

Plant growth rate was inversely proportional to its leaf PGR concentration (Figure 2). Therefore, in order to decrease growth rate, the amount of

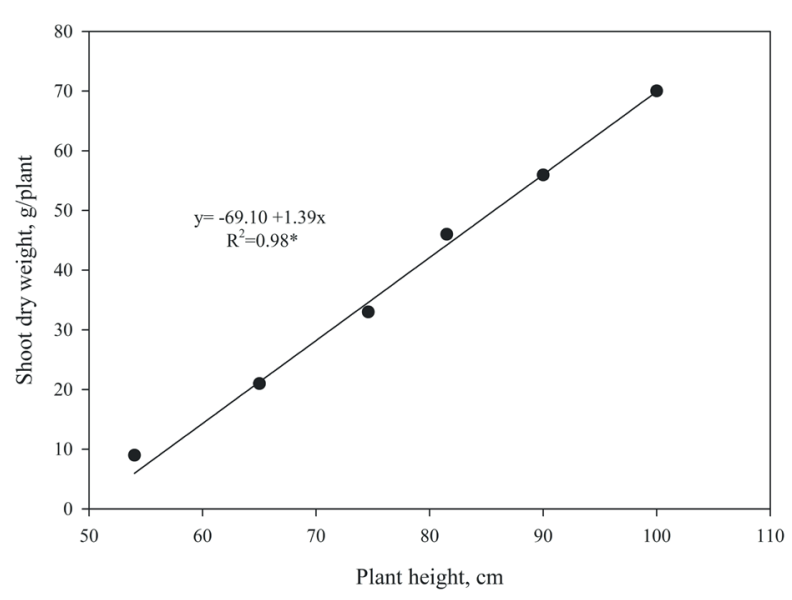

Figure 1. Correlation between the cotton shoot dry matter production and plant height. 


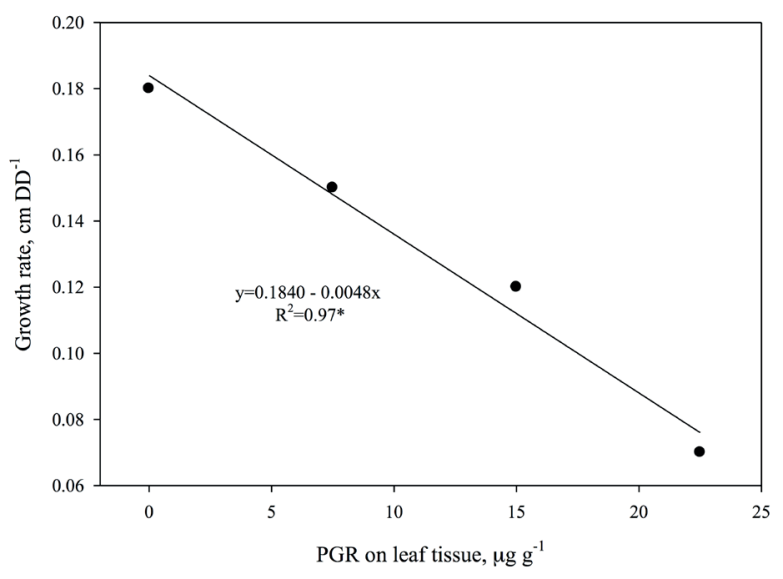

Figure 2. Daily growth rate of cotton plants, as a function of plant growth regulator (PGR) concentration on leaf tissue.

PGR applied must be increased and, for cotton cultivars with low growth rate, the PGR dose would be lower.

For calculating the PGR rate, we assumed that a high-yield plant should have 25 nodes: 5 of them being vegetative nodes, 5 nodes from the top that are not considered productive because they will bear bolls produced after the cut-out and will not be harvested, and 15 being effective reproductive nodes. Considering the ideal plant height at harvesting of $125 \mathrm{~cm}$, the average internodes length would be $5 \mathrm{~cm}$. On average, one new node appears every 3 days (considering a basal temperature of $15^{\circ} \mathrm{C}$ and an average daily temperature of $25^{\circ} \mathrm{C}$ ); hence, the daily growth rate would be $1.6 \mathrm{~cm}^{2} \mathrm{day}^{-1}$.

Three scenarios were designed, based on the daily crop growth rate: i) regular: considering an early cycle cultivar of regular vegetative growth with a daily growth rate of $1.5 \mathrm{~cm}$; ii) favorable: considering a mid-late cycle cultivar of vigorous growth with a daily growth rate of $1.25 \mathrm{~cm}$; iii) very favorable: for those vigorous cultivars plus an environmental condition prone to rank growth, such as good soil humidity and high temperatures (above $32^{\circ} \mathrm{C}$ ), considering a daily growth rate of $1.0 \mathrm{~cm}$. This scenario can be predicted with an accurate weather forecast one week ahead of the mepiquat chloride application.

The PGR rate to be applied as a function of daily growth rate $\left(1.5 \mathrm{~cm}\right.$ day $^{-1}, 1.25 \mathrm{~cm}_{\text {day }}{ }^{-1}$ and $1.0 \mathrm{~cm} \mathrm{day}^{-1}$ ) took into account the plant height, shoot dry weight (estimated by plant height) and PGR concentration needed per plant and per gram of shoot dry weight. This concentration was obtained from the daily growth rate of plants receiving different PGR rates and their shoot dry weight, leaf area and amount of PGR retained in the canopy. With the plant leaf area and the calculated sprayed volume per unit of leaf area, the amount retained per plant, in $\mathrm{mL}$ per plant, for each applied rate $\left(7.5 \mathrm{~g} \mathrm{ha}^{-1}, 15.0 \mathrm{~g} \mathrm{ha}^{-1}\right.$ and $\left.22.5 \mathrm{~g} \mathrm{ha}^{-1}\right)$, was calculated. For this, we considered the shoot dry weight of plants that received the Blue Brilliant and PGR.

An average of PGR needed to achieve each growth rate was obtained, and an equation was fitted to estimate the concentration of PGR needed $\left(\mu \mathrm{g} \mathrm{g}^{-1}\right)$ to obtain the stipulated daily growth rates (1.5 $\mathrm{cm} \mathrm{day}^{-1}, 1.25 \mathrm{~cm}$ day $^{-1}$ and $\left.1.0 \mathrm{~cm} \mathrm{day}^{-1}\right)$. The amount of PGR per plant ( $\left.\mu \mathrm{g}_{\text {plant }}{ }^{-1}\right)$ was the result of the multiplication of the PGR concentration needed per shoot dry weight unity. Finally, this value was multiplied by 90,000 plants (usual plant population for cotton crop), and then the estimated PGR rate was obtained. Curves were fitted and, according to their equations, it was possible to estimate the amount of PGR replacing the " $\mathrm{x}$ " by the measured plant height in the field (Table 1 and Figure 3).

Table 1. Mepiquat chloride rates, as a function of plant height and growing condition. The plant growth regulator rate resulted from the replacement of " $x$ " in the equation by plant height in the first column.

\begin{tabular}{|c|c|c|c|}
\hline Plant height $(\mathrm{cm})$ & Regular & Favorable & Very favorable \\
\hline 40 & 4.40 & 8.75 & 12.48 \\
\hline 60 & 10.24 & 19.41 & 28.52 \\
\hline 80 & 22.72 & 42.39 & 62.48 \\
\hline 100 & 41.84 & 77.69 & 114.36 \\
\hline 120 & 67.60 & 125.31 & 184.16 \\
\hline Equation & $y=12.64-0.538 x+0.0083 x^{2}$ & $\mathrm{y}=24.39-1.007 \mathrm{x}+0.0154 \mathrm{x}^{2}$ & $y=34.16-1.438 x+0.0224 x^{2}$ \\
\hline $\mathrm{R}^{2}$ & 0.99 & 0.99 & 0.99 \\
\hline
\end{tabular}




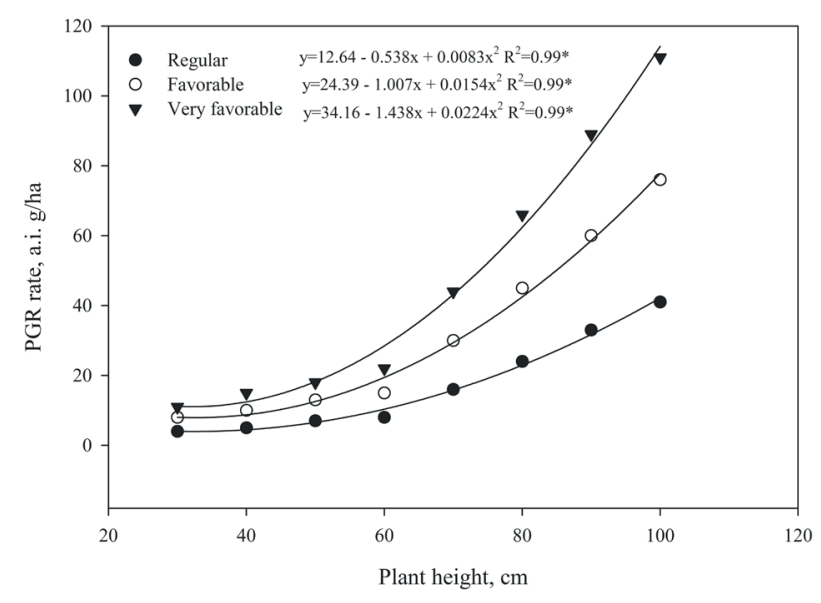

Figure 3. Cotton plant growth regulator (PGR) estimated rate, as a function of plant height in regular, favorable and very favorable growth scenarios.

The estimated PGR rates, as a function of plant height, are shown in Figure 3, based on the following equations: regular: $\mathrm{y}=12.64-0.538 \mathrm{x}+$ $0.0083 \mathrm{x}^{2}$; favorable: $\mathrm{y}=24.39-1.007 \mathrm{x}+0.0154 \mathrm{x}^{2}$; and very favorable: $y=34.16-1.438 x+0.0224 x^{2}$. All scenarios designed have led to low $\mathrm{PGR}$ requirements up to $60 \mathrm{~cm}$ of plant height. At this point, the PGR requirement was different in each growth condition, because the growth vigor was higher in the favorable and very favorable environments, as compared with the regular environment.

An experiment was carried out in the field at Primavera do Leste, Mato Grosso state, Brazil $\left(15^{\circ} 33^{\prime} \mathrm{S}, 54^{\circ} 17^{\prime} \mathrm{W}\right)$, to assess the efficiency of the Crop Growth Rate (CGR) application method in plant height control, as well as in cotton yield and fiber quality. A combination of eight cultivars (late cultivars FM993, IMA 1318, IMACD-8276, FMT709; mid-late cultivars IMACD6001, IMACD07-6035, IMA108-3869; and early cultivar FM 966) and two PGR managements were arranged in a randomized complete block design, replicated four times.

The soil physical-chemical properties $(0-20 \mathrm{~cm}$ depth) showed the following results: $\mathrm{pH}\left(\mathrm{CaCl}_{2}\right)=$ 6.4; $\mathrm{Ca}=5.8 \mathrm{cmol} \mathrm{kg}^{-1} ; \mathrm{Mg}=1.9 \mathrm{cmol} \mathrm{kg}^{-1} ; \mathrm{K}=$ $2.75 \mathrm{cmol} \mathrm{kg}^{-1} ; \mathrm{CEC}=8.9 \mathrm{cmol} \mathrm{kg}^{-1}$; base saturation $=$ $72 \%$; organic matter $=38 \mathrm{~g} \mathrm{~kg}^{-1} ; \mathrm{P}=32.4 \mathrm{mg} \mathrm{kg}^{-1}$; $\mathrm{S}=9 \mathrm{mg} \mathrm{kg}^{-1} ; \mathrm{B}=0.5 \mathrm{mg} \mathrm{kg}^{-1} ; \mathrm{Cu}=1.1 \mathrm{mg} \mathrm{kg}^{-1} ; \mathrm{Fe}=$ $87 \mathrm{mg} \mathrm{kg}{ }^{-1} ; \mathrm{Mn}=13.2 \mathrm{mg} \mathrm{kg}^{-1} ; \mathrm{Zn}=4.5 \mathrm{mg} \mathrm{kg}^{-1}$; sand $=562 \mathrm{~g} \mathrm{~kg}^{-1} ;$ silt $=84 \mathrm{~g} \mathrm{~kg}^{-1}$; clay $=354 \mathrm{~g} \mathrm{~kg}^{-1}$. Climate conditions, such as rainfall and degree-days, are shown in Table 2.
Cotton was planted in rows (0.90 m apart) on December 15 (2012). The final plant density was $10.7 \pm 2.86$ plants $\mathrm{m}^{-2}$. The rates of mepiquat chloride used in the traditional method were based on the manufacturer recommendations, as it follows: $20 \mathrm{~g}$ a.i. ha ${ }^{-1}, 20 \mathrm{~g}$ a.i. ha ${ }^{-1}, 38 \mathrm{~g}$ a.i. ha ${ }^{-1}$ and $38 \mathrm{~g}$ a.i. ha ${ }^{-1}$ at the first, second, third and fourth applications, respectively (more details are given in Table 3), and the use of the CGR method as described previously in Table 1.

The second experiment was conducted in the $2013 / 2014$ growing season. Cotton was sown on December 21 (2013) (8.43 \pm 1.9 plants $\mathrm{m}^{-2}$ density, spaced $0.90 \mathrm{~m}$ between rows). The combination of nine cotton cultivars (late cultivar IMACD-8276; mid-late cultivars IMA08-12427, IMA108-3869, IMA5822B2RF, IMA5672B2RF, IMACD07-6035, IMACV22, IMACV690; and early cultivar IMA5675B2RF) and two PGR managements (PGR treated and non-treated plants) were arranged in a randomized complete block design, replicated four times.

The plant height and average of the top five internodes length were monitored twice a week. When the average of the top five internodes length was greater than $3.5 \mathrm{~cm}$, PGR was applied, as mepiquat chloride, based on equations, as previously mentioned (Table 1 and Figure 3). The rates applied for each cultivar in each treatment are shown in Tables 4 (2012/2013) and 5 (2013/2014).

In both experiments, pearl millet was grown for 85 days and herbicide-dissected (glyphosate $1.92 \mathrm{~kg}$ a.i. $\mathrm{ha}^{-1}$ ) before cotton planting. Cotton was fertilized with phosphorus $\left(120 \mathrm{~kg} \mathrm{ha}^{-1}\right.$ of $\mathrm{P}_{2} \mathrm{O}_{5}$ ) broadcast-applied one week before planting.

Table 2. Precipitation and monthly-accumulated degree-days, during the 2012/2013 and 2013/2014 growing seasons.

\begin{tabular}{lcccc}
\hline \multirow{2}{*}{ Month } & \multicolumn{2}{c}{$2012 / 2013$} & \multicolumn{2}{c}{$2013 / 2014$} \\
\cline { 2 - 5 } & $\begin{array}{c}\text { Rainfall } \\
(\mathrm{mm})\end{array}$ & Degree-day & $\begin{array}{c}\text { Rainfall } \\
(\mathrm{mm})\end{array}$ & Degree-day \\
\hline Dec* & 177.4 & 187.20 & 180.0 & 169.60 \\
Jan & 475.2 & 315.45 & 225.2 & 302.25 \\
Feb & 303.6 & 284.05 & 460.6 & 276.30 \\
Mar & 384.0 & 344.65 & 234.8 & 326.85 \\
Apr & 68.4 & 270.60 & 142.4 & 300.10 \\
May & 14.8 & 272.35 & 0.0 & 257.25 \\
Jun & 48.4 & 264.75 & 7.4 & 241.25 \\
Jul & 0.8 & 215.40 & 28.8 & 240.35 \\
\hline * From December 15 th Base temperature considered: $15^{\circ} \mathrm{C}$ &
\end{tabular}

* From December 15 th. Base temperature considered: $15^{\circ} \mathrm{C}$. 
Nitrogen (140 kg ha-1 as urea) and potassium (120 kg ha-1 of $\mathrm{K}_{2} \mathrm{O}$ as potassium chloride) were applied at 25 and 60 DAE in 2012/2013, and at 30 and 55 DAE in 2013/2014. Pest, disease and weed management practices were standardized for all cultivars, regardless of insect-resistant and herbicidetolerant cultivars. Cotton was defoliated (etephon + cyclanilde at $720+90 \mathrm{~g}$ a.i. ha ${ }^{-1}$ ) when $70 \%$ of bolls were open.

At harvesting, the plant height, number of bolls, boll weight, fiber yield and fiber quality (HVI) were determined. Anova and regression analyses were performed $\left(\right.$ SigmaPlot $\left.^{\circledR}\right)$. The average values for each treatment were compared by the Tukey test $(\mathrm{p}<0.05)$.

\section{RESULTS AND DISCUSSION}

Plant growth regulator rates were higher under the CGR method, when compared with the traditional growers practice (Table 3 ), except for the early cycle cultivar FM966. The amount of PGR applied to this cultivar amounted to $43 \%$ of the growers treatment. On the other hand, the PGR rate applied to other cultivars increased, on average, $24 \%$, ranging $18-36 \%$, if compared with the growers practice. Most of the cultivars received lower PGR rates under the CGR treatment in the first and third applications.

This difference is the result of the low plant dry matter accumulation at the pinhead square stage (B1) ( 40 DAE). Since the CGR method takes into account the plant height and dry matter accumulated, the amount of PGR applied was $70 \%$ lower for the early cycle cultivar and $35-40 \%$ for the other cultivars, as compared with the traditional method. At this stage, shoot development is slower, because the carbohydrates produced by the leaves are used mainly for root growth, and the requirement for PGR is low. Therefore, we argue that the amount of PGR applied using CGR was more consistent with the plants development stage than using the traditional method. In the second application (56 DAE), the PGR rate was lower under the CGR method, as compared to the traditional method, for IMA1318, IMACD8276 and FM966, and higher for the other cultivars, due to the growth scenario at the time of the application. In the third application, the PGR rate was lower in all cultivars and, at the fourth application, was lower for FM966 and higher in the others, when PGR was applied using the CGR method.

There was no interaction of cotton cultivars and PGR application method, except for micronaire (Table 4 and Figure 4). Additionally, the methods of PGR management did not affect cotton growth parameters, yield components and neither fiber length, strength and maturity (Table 3). Plant height at harvesting was affected only by cultivar, and it was the shortest for the early cycle cultivars IMACD-6001 and FM 966 (Table 4). No differences in plant height were observed among the other cultivars. The late maturity cultivar FM 993 had $10 \%$ more nodes than IMACD 6001 (early) and IMACD 8276 (late).

The number of bolls was greater in FMT709. However, the boll weight was greater in IMACD-8276 and IMA108-3869, possibly owing to the lowest number of bolls in such cultivars (Table 4). Gin turnout was significantly lower in the FM966 and

Table 3. Rates of mepiquat chloride per application in each management and cultivar, in the 2012/2013 growing season. Values between parentheses are the difference (as percentage) from the traditional plant growth regulator management.

\begin{tabular}{|c|c|c|c|c|c|c|}
\hline \multirow{2}{*}{ Management } & \multirow{2}{*}{ Cultivar } & \multicolumn{5}{|c|}{ Rate of mepiquat chloride per application $\left(\mathrm{g}\right.$ a.i. ha $\left.^{-1}\right)$ - Scenario } \\
\hline & & $1 \mathrm{st} *$ & 2nd & 3rd & 4th & Total \\
\hline Traditional & All & 20 & 20 & 38 & 38 & 116 \\
\hline \multirow{8}{*}{ CGR } & FM966 & $6(-70) \mathrm{R}$ & $11(-45) \mathrm{R}$ & $13(-66) \mathrm{R}$ & $35(-8) \mathrm{R}$ & $65(-43)$ \\
\hline & IMA108-3869 & $13(-35) \mathrm{F}$ & $31(+55) \mathrm{V}$ & $34(-11) \mathrm{F}$ & $73(+92) \mathrm{F}$ & $150(+30)$ \\
\hline & IMACD6001 & $12(-40) \mathrm{F}$ & $24(+20) \mathrm{V}$ & $30(-21) \mathrm{F}$ & $71(+87) \mathrm{F}$ & $137(+19)$ \\
\hline & IMACD07-6035 & $13(-35) \mathrm{F}$ & $31(+55) \mathrm{V}$ & $36(-5) \mathrm{F}$ & $76(+100) \mathrm{F}$ & $156(+36)$ \\
\hline & FM993 & $12(-40) \mathrm{F}$ & $24(+20) \mathrm{V}$ & $31(-18) \mathrm{F}$ & $70(+84) \mathrm{F}$ & $136(+18)$ \\
\hline & FMT709 & $13(-35) \mathrm{F}$ & $26(+30) \mathrm{V}$ & $28(-26) \mathrm{F}$ & $75(+97) \mathrm{F}$ & $141(+23)$ \\
\hline & IMA1318 & $12(-40) \mathrm{F}$ & $16(-20) \mathrm{F}$ & $30(-21) \mathrm{F}$ & $80(+111) \mathrm{F}$ & $138(+20)$ \\
\hline & IMACD 8276 & $12(-40) \mathrm{F}$ & $17(-15) \mathrm{F}$ & $37(-3) \mathrm{F}$ & $80(+111) \mathrm{F}$ & $145(+26)$ \\
\hline
\end{tabular}

Late cultivars: FM 993, IMA 1318, IMACD-8276, FMT 709; mid-late cultivars: IMACD 6001, IMACD07-6035, IMA108-3869; early cultivar: FM 966. * The 1st, 2nd, 3rd and 4th applications were carried out at 40, 56, 74 and 86 days after emergence (DAE) for the growers pattern management, and at $43,56,79$ and 86 DAE for the crop growth rate method (CGR). Growth scenario: R - regular, considering an early cycle cultivar of regular vegetative growth with a daily growth rate of $1.5 \mathrm{~cm} ; \mathrm{F}$ - favorable, considering a mid-late cycle cultivar of vigorous growth with a daily growth rate of $1.25 \mathrm{~cm}$; V - very favorable, for those vigorous cultivars plus an environmental condition favorable for rank growth, such as good soil humidity and high temperatures (above $32^{\circ} \mathrm{C}$ ), considering a daily growth rate of $1.0 \mathrm{~cm}$. 
IMA03-1318 cultivars, if compared with the other cultivars. Lint yield was significantly higher for IMACD-8276, FMT709 and IMACD07-6035, if compared with IMACD6001, FM966 and FM993. In general, all cultivars showed a good fiber length, strength and maturity (Table 4). Micronaire was lower for IMACD-8276, FM966 and IMA03-1318 under traditional PGR management, if compared with the same cultivars under the CGR method (Figure 4).

The new method was efficient in delivering the right PGR rate, specifically for an early cycle cultivar (IMA5675B2RF), which showed a high sensitivity to PGR. In such a cultivar, PGR would not be necessary, as the plant height at harvesting was adequate for mechanical harvesting (above $1.35 \mathrm{~m}$ for row spacing of $0.90 \mathrm{~m}$ ), even in PGR non-treated plants (Figure 7).

In addition, Gwathmey \& Craig (2003) also reported that the excessive control of vegetative growth on early cycle cultivars with limited potential of growth could result in reduced lint yields. A previous study has shown a high sensitivity of early cultivars to mepiquat chloride (Bogiani \& Rosolem 2009).

The proposed method detected these differences in the total amount of applied PGR. For example, in the 2012/2013 experiment, PGR rates ranged 65-156 g a.i. ha-1 and, in the 2013/2014 experiment, 31.6-164.6 g a.i. $\mathrm{ha}^{-1}$, showing that, depending on the cotton cultivar, the requirement may be significantly increased or decreased, reducing costs in early cultivars and preventing PGR losses and yield reductions.

For example, in the 2012/2013 experiment, FM993, FMT709, IMACD3869, IMACD6001 and IMACD 6035 received PGR based on the very

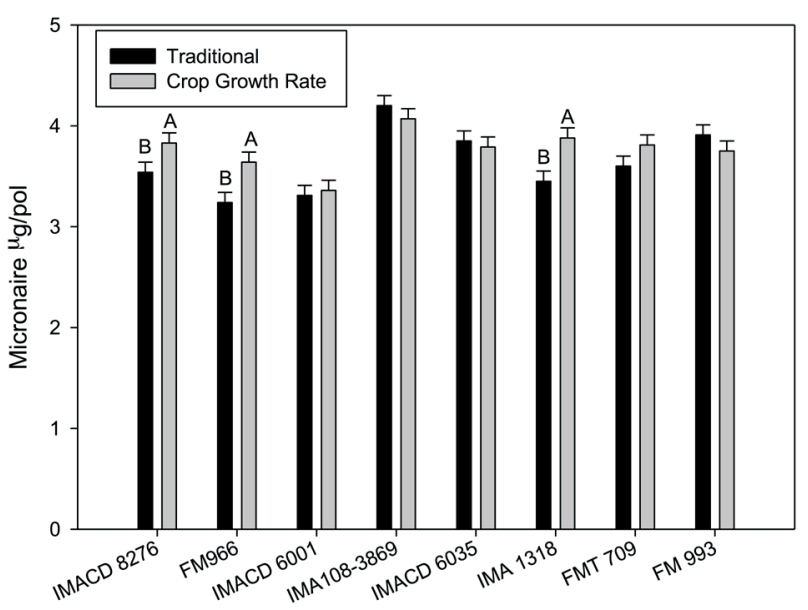

Figure 4. Micronaire of cotton cultivars under traditional and Crop Growth Rate (CGR) managements, in the 2012/2013 growing season. $\mathrm{A}>\mathrm{B}$ in the same cultivar $(\mathrm{p}<0.05)$. Late cultivars: FM993, IMA1318, IMACD-8276, FMT709; mid-late cultivars: IMACD6001, IMACD07-6035, IMA108-3869; early cultivar: FM966.

Table 4. Growth characteristics, yield components and fiber quality of cotton cultivars and methods of plant growth regulator management, in the 2012/2013 growing season.

\begin{tabular}{|c|c|c|c|c|c|c|c|c|c|}
\hline \multirow{2}{*}{ Cultivar } & Height & \multirow{2}{*}{$\mathrm{NN}$} & Bolls & Boll weight & GT & Lint yield & LEN & STR & \multirow{2}{*}{ MAT } \\
\hline & $\mathrm{cm}$ & & $\mathrm{m}^{2}$ & $\mathrm{~g}$ & $\%$ & $\mathrm{~kg} \mathrm{ha}^{-1}$ & $\mathrm{~mm}$ & $\mathrm{cN} / \mathrm{tex}$ & \\
\hline IMACD6001 & $119 \mathrm{~b}$ & $25.4 \mathrm{~b}$ & $92 \mathrm{c}$ & $5.1 \mathrm{ab}$ & $41.6 \mathrm{a}$ & $1,601 \mathrm{c}$ & $29.6 \mathrm{abc}$ & $29.6 \mathrm{ab}$ & $82.6 \mathrm{c}$ \\
\hline FM966 & $121 \mathrm{~b}$ & $25.7 \mathrm{ab}$ & $89 \mathrm{c}$ & $4.9 \mathrm{ab}$ & $38.7 \mathrm{~b}$ & $1,631 \mathrm{c}$ & $30.1 \mathrm{a}$ & $29.2 \mathrm{ab}$ & $83.1 \mathrm{c}$ \\
\hline IMACD-8276 & $130 \mathrm{a}$ & $25.5 \mathrm{~b}$ & $86 \mathrm{c}$ & $5.4 \mathrm{a}$ & $41.9 \mathrm{a}$ & $2,054 \mathrm{a}$ & $29.0 \mathrm{bc}$ & $29.2 \mathrm{abc}$ & $83.1 \mathrm{c}$ \\
\hline IMA108-3869 & $132 \mathrm{a}$ & $27.1 \mathrm{ab}$ & 98 bc & $5.4 \mathrm{a}$ & $41.8 \mathrm{a}$ & $1,967 \mathrm{ab}$ & $29.7 \mathrm{ab}$ & $29.2 \mathrm{ab}$ & $84.8 \mathrm{a}$ \\
\hline IMACD07-6035 & $132 \mathrm{a}$ & $27.3 \mathrm{ab}$ & $102 \mathrm{bc}$ & $5.1 \mathrm{ab}$ & $42.4 \mathrm{a}$ & $2128 \mathrm{a}$ & $30.0 \mathrm{a}$ & $30.1 \mathrm{a}$ & $83.8 \mathrm{~b}$ \\
\hline FMT709 & $132 \mathrm{a}$ & $26.9 \mathrm{ab}$ & $121 \mathrm{a}$ & $4.5 \mathrm{~b}$ & $42.0 \mathrm{a}$ & $2,069 \mathrm{a}$ & $29.2 \mathrm{bc}$ & $28.6 \mathrm{bc}$ & $83.8 \mathrm{~b}$ \\
\hline FM993 & $134 \mathrm{a}$ & $27.9 \mathrm{a}$ & $113 \mathrm{bc}$ & $4.7 \mathrm{~b}$ & $41.4 \mathrm{a}$ & $1,870 \mathrm{abc}$ & $29.3 \mathrm{bc}$ & $29.3 \mathrm{ab}$ & $84.1 \mathrm{a}$ \\
\hline IMA03-1318 & $136 \mathrm{a}$ & $26.0 \mathrm{ab}$ & $100 \mathrm{ab}$ & $5.0 \mathrm{ab}$ & $37.8 \mathrm{~b}$ & $1,768 \mathrm{bc}$ & $29.0 \mathrm{c}$ & $27.9 \mathrm{c}$ & $83.0 \mathrm{c}$ \\
\hline \multicolumn{10}{|l|}{ Method } \\
\hline CGR & 128 & 26.5 & 101 & 5.1 & 40.9 & 2,106 & 29.5 & 29.3 & 83.7 \\
\hline Traditional & 131 & 26.5 & 99 & 5.0 & 41.0 & 2,045 & 29.5 & 29.2 & 83.4 \\
\hline Source of variation & & & & & $P$ values & & & & \\
\hline Cultivar (C) & 0.01 & 0.19 & 0.01 & 0.07 & 0.01 & 0.01 & 0.01 & 0.04 & 0.01 \\
\hline Method (M) & 0.11 & 0.94 & 0.54 & 0.44 & 0.57 & 0.55 & 0.75 & 0.84 & 0.02 \\
\hline $\mathrm{C} \times \mathrm{M}$ & 0.63 & 0.95 & 0.91 & 0.51 & 0.86 & 0.56 & 0.80 & 0.95 & 0.24 \\
\hline CV $(\%)$ & 5.54 & 8.20 & 16.83 & 11.93 & 2.81 & 14.78 & 2.35 & 4.68 & 0.73 \\
\hline
\end{tabular}


favorable condition (Table 3), because, at that time, the weather forecast indicated high temperatures in the next few days, what, in fact, was confirmed (average high temperatures in the following week after height evaluation were $32.7^{\circ} \mathrm{C}$ ). This method showed to be particularly important in early and intermediate cycles, because those cultivars are more sensitive to the excess of PGR (Bogiani \& Rosolem 2009), if compared to late cultivars. As the input in the formula is plant height, the amount of PGR applied early in the crop season will always be lower and will increase as plants age.

In addition, higher PGR rates were applied for the CGR method, if compared with the traditional recommendation, most likely due to the amount applied in the fourth application (86 DAE) (Table 3), when PGR rates were almost double the traditional management approach. The possibility of PGR losses due to rainfall occurring after application does exist (Echer \& Rosolem 2012) and it could be a disadvantage of this method, once the PGR rate increases as plants grow higher.

Johnson \& Pettigrew (2006) also observed no interaction between PGR management and cotton cultivars on plant height, as reported in our experiment (2012/2013). On the other hand, the interaction was significant for lint yield, contrary to what we found in this experiment. O'Berry et al. (2009) suggested that cotton cultivars may respond differently to PGR application, during certain years, even if actual plant height reductions are not significant. Moreover, no difference in plant height between CGR and traditional management practices was observed in the 2012/2013 experiment (Table 5), but some cultivars exhibited micronaire variation (Figure 4).

The PGR rates applied in the 2013/2014 growing season resulted in great differences among cultivars. Five cultivars were classified as having a high PGR requirement (IMA08-12427, IMA108-3869, IMACD07-6035, IMACD-8276 and IMACV22), two as intermediate (IMA5672B2RF and IMACV-690), one as low (IMA5822B2RF) and one as very low (IMA5675B2RF) (Table 5).

Plant height was different among cotton cultivars without PGR application at 65 DAE. IMA08-12427 and IMACV22 had the tallest, and IMA5675B2RF the shortest plants, at 110 DAE (Figure 5). Differences in plant height were also observed at 65 DAE in PGR-treated plants, and IMACV22 and IMA076035 had the highest plants, while IMA5675B2RF had the shortest plants at 110 DAE (Figure 5).

There was a significant interaction of cultivars and PGR application for plant height (Figure 6), number of bolls (Figure 7), boll weight (Figure 8) and fiber length (Figure 9). However, no interaction was observed for number of nodes, fiber yield, gin turnout, fiber strength, micronaire and maturity (Table 6).

The final plant height was lower for PGRtreated plants in all cultivars. Additionally, PGR nontreated plants of IMA5675B2RF and IMACV690 had an appropriate plant height for mechanical harvest $(\sim 1.30 \mathrm{~m})$, showing that PGR would not be necessary for these cultivars (Figure 6).

The number of nodes was dependent on the cultivars, and the early maturing cultivar

Table 5. Rates of mepiquat chloride per application, according to each cultivar, in the 2013/2014 growing season.

\begin{tabular}{|c|c|c|c|c|c|c|}
\hline \multirow{2}{*}{ Cultivar } & \multicolumn{5}{|c|}{ Rate of mepiquat chloride per application (g a.i. ha $\left.{ }^{-1}\right)$} & \multirow[b]{2}{*}{ Total } \\
\hline & $1 \mathrm{st} *$ & 2nd & $3 \mathrm{rd}$ & 4th & 5 th & \\
\hline IMA08-12427 & $9.0 \mathrm{~F}$ & $12.3 \mathrm{~F}$ & $14.3 \mathrm{~F}$ & $51.6 \mathrm{~V}$ & $69.1 \mathrm{~F}$ & 154.0 \\
\hline IMA108-3869 & $7.5 \mathrm{~F}$ & $12.2 \mathrm{~F}$ & $14.5 \mathrm{~F}$ & $53.5 \mathrm{~V}$ & $68.5 \mathrm{~F}$ & 156.2 \\
\hline IMA5672B2RF & $9.4 \mathrm{~F}$ & $11.5 \mathrm{~F}$ & $13.2 \mathrm{~F}$ & $39.0 \mathrm{~V}$ & $54.1 \mathrm{~F}$ & 122.5 \\
\hline IMA5675B2RF & $8.1 \mathrm{R}$ & $11.1 \mathrm{R}$ & $12.3 \mathrm{R}$ & $0.0 \mathrm{R}$ & $0.0 \mathrm{R}$ & 31.6 \\
\hline IMA5822B2RF & $4.3 \mathrm{R}$ & $5.6 \mathrm{R}$ & $6.6 \mathrm{R}$ & $16.8 \mathrm{R}$ & $35.0 \mathrm{R}$ & 66.7 \\
\hline IMACD07-6035 & $9.2 \mathrm{~F}$ & $12.6 \mathrm{~F}$ & $14.8 \mathrm{~F}$ & $55.5 \mathrm{~V}$ & $74.7 \mathrm{~F}$ & 164.6 \\
\hline IMACD8276 & $9.9 \mathrm{~F}$ & $13.0 \mathrm{~F}$ & $14.2 \mathrm{~F}$ & $52.0 \mathrm{~V}$ & $67.8 \mathrm{~F}$ & 154.4 \\
\hline IMACV22 & $8.8 \mathrm{~F}$ & $12.6 \mathrm{~F}$ & $14.8 \mathrm{~F}$ & $54.4 \mathrm{~V}$ & $73.1 \mathrm{~F}$ & 163.8 \\
\hline IMACV690 & $9.5 \mathrm{~F}$ & $11.5 \mathrm{~F}$ & $13.4 \mathrm{~F}$ & $38.6 \mathrm{~V}$ & $58.9 \mathrm{~F}$ & 127.1 \\
\hline
\end{tabular}

Late cultivar: IMACD-8276; mid-late cultivars: IMA08-12427, IMA108-3869, IMA5822B2RF, IMA5672B2RF, IMACD07-6035, IMACV22, IMACV690; early cultivar: IMA5675B2RF. * The 1st, 2nd, 3rd, 4th and 5th applications were carried out at 40, 48, 61, 68 and 89 days after emergence. Growth scenario: R - regular, considering an early cycle cultivar of regular vegetative growth with a daily growth rate of $1.5 \mathrm{~cm} ; \mathrm{F}$ - favorable, considering a mid-late cycle cultivar of vigorous growth with a daily growth rate of $1.25 \mathrm{~cm} ; \mathrm{V}$ - very favorable: for those vigorous cultivars plus an environmental condition favorable for rank growth, such as good soil humidity and high temperatures (above $32{ }^{\circ} \mathrm{C}$ ), considering a daily growth rate of $1.0 \mathrm{~cm}$. 

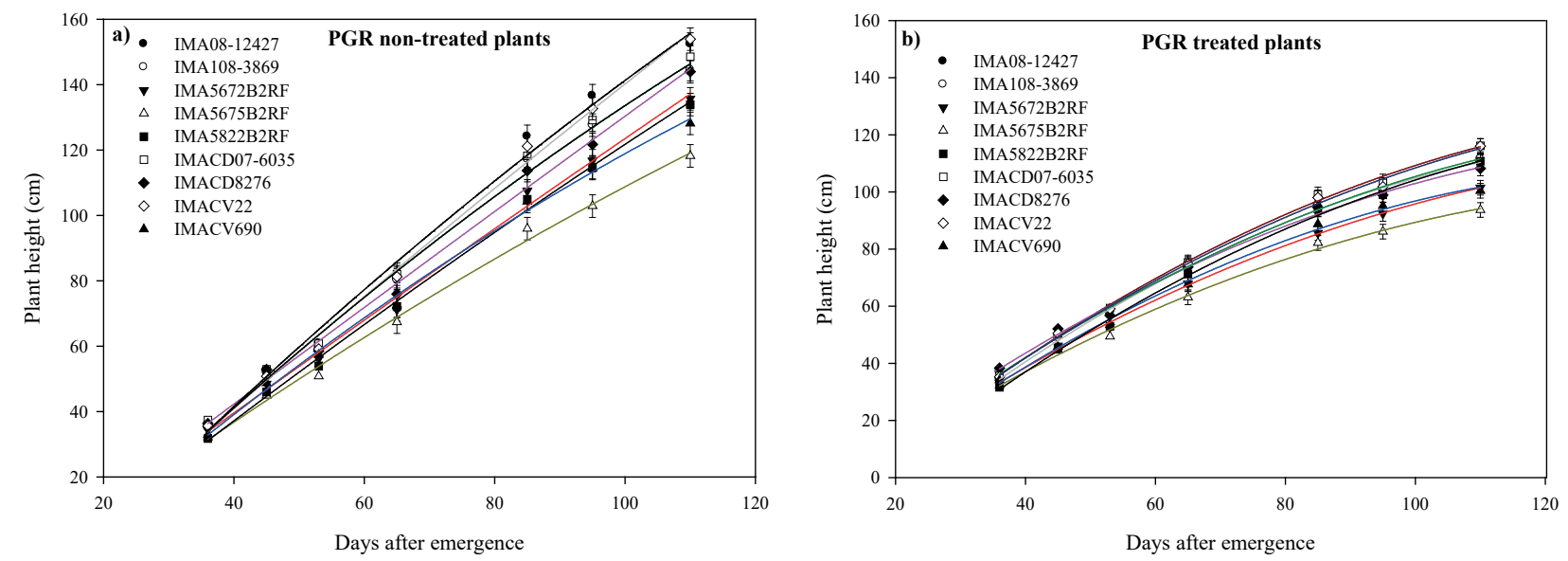

Figure 5. Plant height in PGR non-treated (a) and treated plants (b), as a function of cotton cultivar and days after emergence, in the 2013/2014 growing season. Late cultivar: IMACD-8276; mid-late cultivars: IMA08-12427, IMA108-3869, IMA5822B2RF, IMA5672B2RF, IMACD07-6035, IMACV22, IMACV690; early cultivar: IMA5675B2RF.

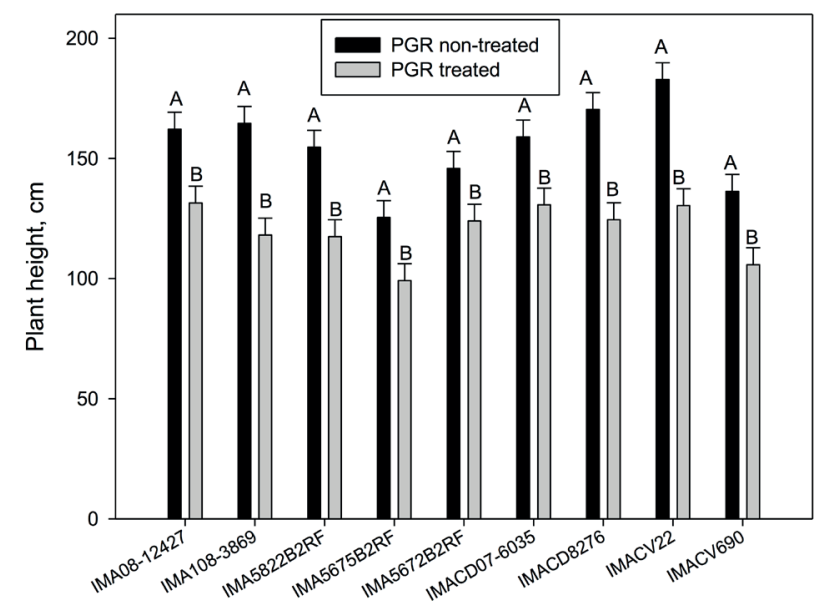

Figure 6. Plant height of cotton cultivars at harvesting, as a function of plant growth regulator (PGR) treatments, in the 2013/2014 growing season. Capital letters compare plant growth regulator treatments in each cultivar (Tukey, $\mathrm{p}<0.05$ ). Late cultivar: IMACD-8276; mid-late cultivars: IMA08-12427, IMA108-3869, IMA5822B2RF, IMA5672B2RF, IMACD07-6035, IMACV22, IMACV690; early cultivar: IMA5675B2RF.

IMA5675B2RF showed the lowest number of nodes, if compared with IMA08-12427 and IMACV22LL. No differences were observed among the other cultivars (Table 5). Gin turnout was lower on the early maturity cultivars IMA5672B2RF, IMA5675B2RF, IMA5822B2RF and IMA08-12427, if compared with late and mid-late maturing cultivars (Table 6). Lint yield was decreased for IMA5672B2RF, if compared with IMACD07-6035 and IMACV690, but no differences among the others cultivars were

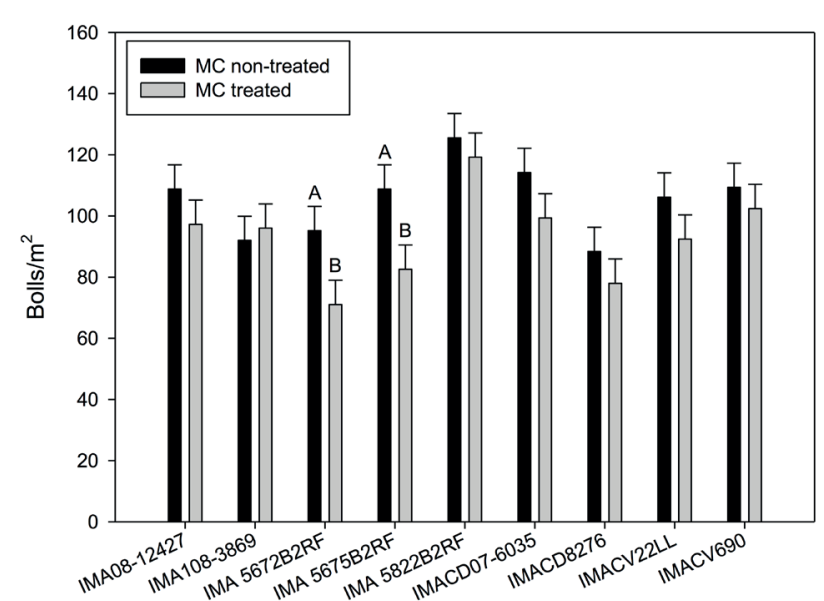

Figure 7. Number of bolls in cotton cultivars, as affected by plant growth regulator (PGR) treatments, in the 2013/2014 growing season. Capital letters compare PGR treatments in each cultivar (Tukey, $\mathrm{p}<0.05$ ).

observed. Micronaire and maturity ratio were not different among cotton cultivars (Table 6).

A $2 \%(40.25-39.46)$ decrease in gin turnout was observed in PGR-treated plants. Otherwise, fiber strength was increased by the CGR treatment (Table 6). The number of bolls for PGR-treated plants was reduced, if compared with non-treated plants of IMA5672B2RF and IMA5675B2RF (Figure 7), what may explain the higher boll weight observed in these cultivars (Figure 8). Finally, the interaction of cultivars and PGR, for fiber length, was significant, and the PGR treatment decreased the length of IMACV22LL and IMACV690 (Figure 9). 
In two years of evaluation, the PGR management did not affect lint yield (Tables 5 and 6). Studies with two or more years of field experiment or different locations have shown that mepiquat chloride responses in yield are dependent upon environmental conditions (Zhao et al. 2017), such as season length, because the mepiquat chloride treatment increases fruit retention at lower fruiting branches. In years with a short growing season, mepiquat chloride tends to increase yield (Kerby et al. 1986). Otherwise, in a full growing season, the bolls produced at the top may

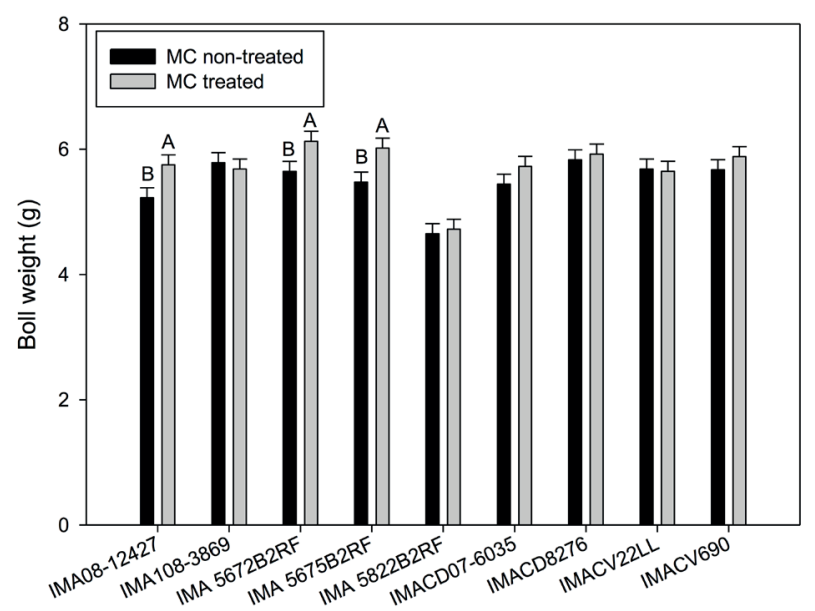

Figure 8 . Boll weight of cotton cultivars, as affected by plant growth regulator (PGR) treatments, in the 2013/2014 growing season. Capital letters compare PGR treatments in each cultivar (Tukey, $\mathrm{p}<0.05$ ). mature, and differences in yield disappear (Zhao \& Oosterhuis 2000).

Mepiquat chloride had an inconsistent effect on the lint percentage, with a neutral effect for the 2012/2013 and a negative effect for the 2013/2014 experiment. PGR application has been reported to reduce the lint percentage in a wide range of environments (Cathey \& Meredith 1988, Biles \& Cothren 2001, Johnson \& Pettigrew 2006, Ren et al. 2013), and this decrease has been attributed to an increase in seed weight (Biles \& Cothren

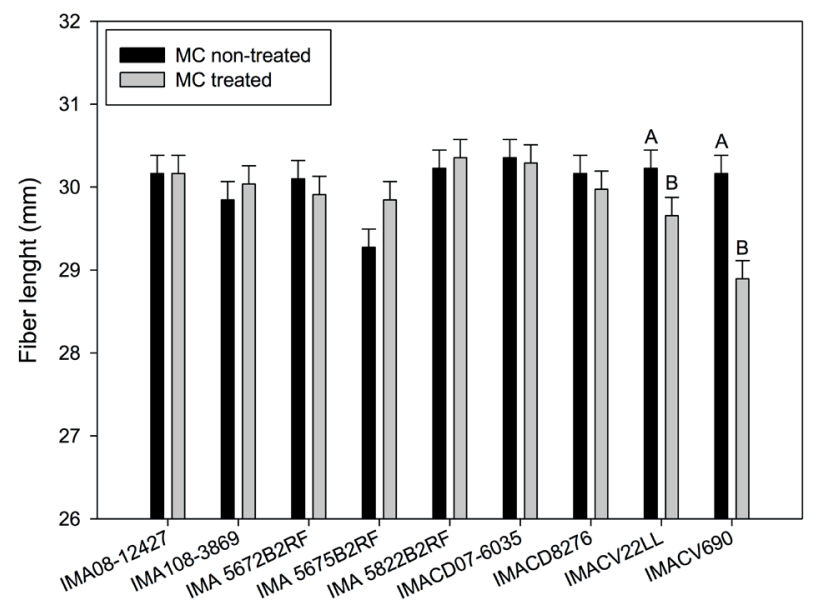

Figure 9. Fiber length of cotton cultivars treated and non-treated with plant growth regulator (PGR), in the 2013/2014 growing season. Capital letters compare PGR treatments in each cultivar (Tukey, $\mathrm{p}<0.05$ ).

Table 6. Yield components and fiber quality parameters, as affected by cultivars and PGR treatments, in the 2013/2014 growing season.

\begin{tabular}{|c|c|c|c|c|c|c|}
\hline Cultivar & NN & $\begin{array}{c}\text { GT } \\
\% \\
\end{array}$ & $\begin{array}{c}\text { Lint yield } \\
\mathrm{kg} \mathrm{ha}^{-1}\end{array}$ & $\begin{array}{c}\text { STR } \\
\mathrm{cN} / \text { tex } \\
\end{array}$ & $\begin{array}{c}\text { MIC } \\
\mu \mathrm{g} \mathrm{pol}^{-1}\end{array}$ & MAT \\
\hline IMA08-12427 & $24.50 \mathrm{a}$ & $36.62 \mathrm{de}$ & $1,889 \mathrm{ab}$ & $31.73 \mathrm{ab}$ & 3.79 & 83.75 \\
\hline IMA108-3869 & $23.63 \mathrm{ab}$ & $42.10 \mathrm{a}$ & $2,123 \mathrm{ab}$ & $32.45 \mathrm{a}$ & 4.09 & 84.88 \\
\hline IMA 5672B2RF & $23.83 \mathrm{ab}$ & $37.91 \mathrm{~cd}$ & $1,667 \mathrm{~b}$ & $29.25 \mathrm{c}$ & 4.00 & 84.25 \\
\hline IMA 5675B2RF & $20.43 \mathrm{~b}$ & $38.83 \mathrm{c}$ & $2,018 \mathrm{ab}$ & $30.34 \mathrm{bc}$ & 3.85 & 84.00 \\
\hline IMA 5822B2RF & $24.03 \mathrm{ab}$ & $35.46 \mathrm{e}$ & $1,910 \mathrm{ab}$ & $32.01 \mathrm{a}$ & 4.09 & 84.75 \\
\hline IMACD07-6035 & $24.03 \mathrm{ab}$ & $42.79 \mathrm{a}$ & $2,438 \mathrm{a}$ & $31.95 \mathrm{ab}$ & 4.02 & 84.63 \\
\hline IMACD8276 & $23.35 \mathrm{ab}$ & $41.84 \mathrm{ab}$ & $1,903 \mathrm{ab}$ & $31.11 \mathrm{ab}$ & 4.10 & 84.75 \\
\hline IMACV22LL & $25.55 \mathrm{a}$ & $42.62 \mathrm{a}$ & $2,157 \mathrm{ab}$ & $31.50 \mathrm{ab}$ & 4.07 & 84.88 \\
\hline IMACV690 & $22.68 \mathrm{ab}$ & $40.52 \mathrm{~b}$ & $2,389 \mathrm{a}$ & $31.70 \mathrm{ab}$ & 4.07 & 85.00 \\
\hline PGR & & & & & & \\
\hline MC (non-treated) & 24.07 & $40.25 \mathrm{a}$ & 2,139 & $31.09 \mathrm{~b}$ & 4.01 & 84.58 \\
\hline $\mathrm{MC}$ (treated) & 23.04 & $39.46 \mathrm{~b}$ & 1,971 & $31.59 \mathrm{a}$ & 4.00 & 84.50 \\
\hline Source of variation & \multicolumn{6}{|c|}{$P$ values } \\
\hline Cultivar (C) & 0.01 & 0.01 & 0.01 & 0.01 & 0.28 & 0.03 \\
\hline PGR (P) & 0.08 & 0.01 & 0.05 & 0.04 & 0.80 & 0.66 \\
\hline $\mathrm{C} \times \mathrm{P}$ & 0.56 & 0.61 & 0.77 & 0.29 & 0.64 & 0.31 \\
\hline $\mathrm{CV}(\%)$ & 10.60 & 2.43 & 17.76 & 3.24 & 7.16 & 0.96 \\
\hline
\end{tabular}

NN: number of nodes; GT: gin turnout; STR: strength; MIC: micronaire; MAT: maturity; MC: mepiquat chloride; PGR: plant growth regulator. Late cultivar: IMACD-8276; mid-late cultivars: IMA08-12427, IMA108-3869, IMA5822B2RF, IMA5672B2RF, IMACD07-6035, IMACV22, IMACV690; early cultivar: IMA5675B2RF. 
2001), although seed weight was not evaluated in this study.

Mepiquat chloride-treated cotton plants have also shown inconsistent changes in micronaire (Cathey \& Meredith 1988, Siebert \& Stewart 2006). In the present study, it was observed, in the 2012/2013 experiment, that the PGR management based on the new method could prevent a decrease in micronaire. Fiber length was unaffected in 2012/2013, as observed by Heilman (1985), and decreased by the mepiquat chloride treatment, in 2013/2014, contrary to data from O'Berry et al. (2009), who reported an increase in fiber length, as a response to mepiquat chloride rates. Fiber strength was not affected by the PGR management in 2012/2013, corroborating the findings of Heilman (1985), but a positive effect was obtained by the mepiquat chloride treatment in $2013 / 2014$, consistently with previous studies (Cathey \& Meredith 1988, Ren et al. 2013), following the application of PGR to cotton.

\section{CONCLUSIONS}

1. The proposed method is efficient in defining the plant growth regulator rates for cotton cultivars, and results in economy of mepiquat chloride in early cycle cultivars, preserving lint yield and fiber quality;

2. The easy applicability of this method distinguishes it from other methods, because all the user needs to know is the actual plant height, cultivar maturity group and weather forecast for the next week.

\section{REFERENCES}

APHALO, P. J.; BALLARE, C. L. On the importance of information-acquiring systems in plant-plant interactions. Functional Ecology, v. 9, n. 1, p. 5-14, 1995.

BILES, S. P.; COTHREN, J. T. Flowering and yield response of cotton to application of mepiquat chloride and PGR-IV. Crop Science, v. 41, n. 6, p. 1834-1837, 2001.

BOGIANI, J. C.; ROSOLEM, C. A. Sensibility of cotton cultivars to mepiquat chloride. Pesquisa Agropecuária Brasileira, v. 44, n. 10, p. 1246-1253, 2009.

CATHEY, G. W.; MEREDITH, W. R. Cotton response to planting date and mepiquat chloride. Agronomy Journal, v. 80, n. 3, p. $463-466,1988$.

ECHER, F. R.; ROSOLEM, C. A. Plant growth regulator losses in cotton as affected by adjuvants and rain. Ciência Rural, v. 42, n. 12, p. 2138-2144, 2012.
FERREIRA, A. C. B. Plant growth regulators in cotton. Campina Grande: Embrapa Algodão, 2014. (Technical communication, 373).

GU, S. et al. Modelling the structural response of cotton plants to mepiquat chloride and population density. Annals of Botany, v. 114, n. 4, p. 877-887, 2014.

GWATHMEY, C. O.; CRAIG JUNIOR, C. C. Managing earliness in cotton with mepiquat-type growth regulators. 2003. Available at: $<\mathrm{http}: / / \mathrm{www}$. plantmanagementnetwork. $\mathrm{org} / \mathrm{pub} / \mathrm{cm} / \mathrm{research} / 2003 / \mathrm{mepiquat} />$. Access on: 15 Feb., 2017.

HEILMAN, M. D. Effect of mepiquat chloride and nitrogen levels on yield, growth characteristics, and elemental composition of cotton. Journal of Plant Growth Regulation, v. 4, n. 1, p. 41-47, 1985.

JOHNSON, J. T.; PETTIGREW, W. T. Effects of mepiquat pentaborate on cotton cultivars with different maturities. Journal of Cotton Science, v. 10, n. 2, p. 128-135, 2006.

KERBY, T. A.; HAKE, K.; KEELEY, M. Cotton fruiting modification with mepiquat chloride. Agronomy Journal, v. 78, n. 5, p. 907-912, 1986.

O'BERRY, N. B. et al. Differential responses of cotton cultivars when applying mepiquat pentaborate. Agronomy Journal, v. 101, n. 1, p. 25-31, 2009.

REDDY, V. R.; TRENT, A.; ACOCK, B. Mepiquat chloride and irrigation versus cotton growth and development. Agronomy Journal, v. 84, n. 6, p. 930-933, 1992.

REN, X. et al. Managing mepiquat chloride and plant density for optimal yield and quality of cotton. Field Crops Research, v. 149, n. 1, p. 1-10, 2013.

ROSOLEM, C. A.; OOSTERHUIS, D. M.; SOUZA, F. $\mathrm{S}$. Cotton response to mepiquat chloride and temperature. Scientia Agricola, v. 70, n. 2, p. 82-87, 2013.

SIEBERT, J. D.; STEWART, A. M. Influence of plant density on cotton response to mepiquat chloride application. Agronomy Journal, v. 98, n. 6, p. 1634-1639, 2006.

WANG, L. et al. The effect of mepiquat chloride on elongation of cotton (Gossypium hirsutum L.) internode is associated with low concentration of gibberellic acid. Plant Science, v. 225, n. 1, p. 15-23, 2014.

ZHAO, D.; OOSTERHUIS, D. M. Pix plus and mepiquat chloride effects on physiology, growth, and yield of fieldgrown cotton. Journal of Plant Growth Regulation, v. 19, n. 4, p. 415-422, 2000.

ZHAO, W. et al. Interactions of single mepiquat chloride application at different growth stages with climate, cultivar, and plant population for cotton yield. Crop Science, v. 57, n. 3, p. 1713-1724, 2017. 